monthly 'Eintopfgericht' Sunday alone, when a majority of the population contributes to 'winterhelp' the savings resulting from restricting the midday meal to one dish, provided more than 25 million marks.

The next hall, 'Die Erhaltung des Lebens', illustrates the protection of public health in all its aspects, and the visitor can see in it many of the latest devices of preventive and curative medicine, ranging from occupational therapy and radium treatment to the latest Junkers 'Sanitätsflugzeuges'. The sanitary and educational activities of the Nazi party are also amply illustrated. A feature of the hall is a model marriage consultation centre, to which attention is attracted by illuminated curves, correlated with pictures of social conditions, of the birth-and deathrates since 1820. They show that the birth-rate rose from 1820 until 1875 , and fell in response to increasing industrialisation between 1875 and 1933, when it again assumed an upward trend. The inclination of the death-rate follows, as usual, that of the birth-rate. The elevation of the birth-rate in the new regime has been secured not only by propaganda but also by State aid, 20 marks a month being given for each child in families of more than three children, provided they are 'racially healthy'. It should be added that these consultation centres will increase in importance, for further measures for the betterment of national health are to be introduced very shortly, including legislation for health certificates before marriage.

Special attention is also paid to racial 'purity', Gobineau being given an important niche in the portrait gallery of great men who have influenced the Nazi philosophy. In one popular section the Nordic farmer and fighter is glorified in pictures reminiscent of juvenile editions of the "Nibelungensage", surmounted by the statement that "There is nothing more precious on this earth than the seeds of noble blood". On the opposite wall a quotation from "Mein Kampf"' stands out in equally bold relief : "Indem ich für die Deutsches Zukunst kämpfe, muss ich kämpfen fur die Deutsche Scholle, und muss ich kämpfen fur den Deutschen Bauern". In an adjoining section a propagandic pedigree of the 'Führer' emphasises his association with the peasant class. The inevitable Jew-baiting takes the form of a series of 'selected' pictures of Semitic types bearing the sarcastic legend "Der Jude Harry Chaim genannt Heinrich Heine sagt im Buch der Lieder : 'Alle Menschen gleich geboren, sind ein adliges Geschlecht'." Alongside are several anti-Semitic cartoons, supported by Herr Hitler's opinion that the Jew can never be a German and that he will always work for the 'Grossere Idee' of his own race. The organisers of the Exhibition would have done better if they had refrained from degrading an otherwise excellent scientific exhibition with such propaganda.

The Exhibition concludes with a 'Mikrovivarium' and a section entitled 'Wohnung and Siedlung'. In the former, living micro-organisms and parasites are projected on a screen and explained by attendant demonstrators. In the latter, a series of models illustrates the improvement of housing conditions for the working classes, the central attraction being a full-size example of the suburban houses provided for working men. As one leaves the Exhibition, one feels that modern Germany has not only caught something of the spirit of the lines which adorn the cover of this journal, but has also succeeded to an admirable degree in translating it into practice.

I am indebted to the Hon. Mrs. Ursula Grant Duff and Dr. Bruno Gebhard, scientific director of the Exhibition, for many courtesies in connexion with my biological inquiries in Germany.

Cenric Dover.

\title{
Constitution and Properties of Some Non-Ferrous Metals and Alloys
}

$\mathrm{T}$ $\mathrm{HE}$ spring meeting of the Institute of Metals was held on March 6-7, in the hall of the Institution of Mechanical Engineers.

To all interested in the lead-tin-antimony alloys, and particularly those used for type metals, the paper by Frances D. Weaver will be of especial value. In addition to the working out of at any rate the main features of this diagram, a considerable amount of data is available concerning the hardness properties of those alloys most commonly employed.

Prof. D. Hanson, in collaboration with Mr. E. J. Sandford, has continued his work on the influence of small amounts of other elements on the properties of tin. The metals investigated in the present work are aluminium, manganese and bismuth, the results with the first metal being perhaps particularly important in that there is a very definite time effect. The greatly improved properties obtained immediately after preparation are not permanent; deterioration of the alloy commences at the skin and spreads slowly inwards and spontaneous cracking takes place. Bismuth also increases the tensile strength of tin very considerably and refines the grain size.

Mr. W. E. Prytherck has examined the mechanical properties of some wrought magnesium alloys, and although no alloys of this metal have yet been produced which respond to heat treatment in the manner which is characteristic of certain well-known aluminium alloys, some of the materials studied have distinctly interesting and promising properties. The work which they have carried out over a number of years on the investigation of unsoundness in aluminium alloy castings is continued by Prof. Hanson and Mr. I. G. Slater, who have examined the effect of the pressure of the atmosphere under which a metal solidifies. They have shown that pressures from fifty to a hundred pounds per square inch are sufficient to remove all visible traces of pin-holes from sand-cast ingots, and that the densities of such castings, particularly those prepared under the higher pressures, are appreciably greater than can be obtained from ingots poured from melts treated by the various de-gassing processes. The tensile properties of certain alloys are considerably improved by solidification under pressure, but the fact is noted that in some instances, reheating the casting, by causing the liberation of the gases contained in solution, may give rise to blisters and cavities.

The penetration of molten solders into strained non-ferrous metals has been examined by a number of workers. Mr. L. J. G. van Ewijk contributes an account of a similar type of cracking in heat-treated nickel-chromium steel. The zine chloride flux is shown to be innocuous, and it is clear from the intercrystalline nature of the fracture that the penetration here is of exactly the same order as that which has been found in non-ferrous alloys. One of the interesting 
features of the work is the considerable difference in the susceptibility to this type of embrittlement to be found in the various nickel-chromium steels themselves. There is some indication, however, that a high impact value results in a material which is relatively immune. Tests carried out on two plain carbon steels suggest that these are not liable to fracture under the conditions of the test. Whether, however, this is due merely to the composition of the material, or to the fact that the tensile strengths of these plain earbon steels were distinctly lower than those of the nickel-chromium ones, whence presumably the carbon steel contained less internal stress, is not clear.

The effect of five years exposure to urban atmospheric conditions on the strength and electrical resistance of some non-ferrous wires is reported on by Mr.J.C.Hudson. The work shows that electrical resistance measurements may be used to give a fair idea of the extent to which corrosion proceeds. Among the materials investigated copper stands out pre-eminently, whilst the most corroded material of all was galvanised iron wire, which rapidly failed once the zinc coating had been corroded away.

Dr. H. J. Gough and Mr. D. G. Sopwith give an account of further experiments on atmospheric action in connexion with fatigue. The results of the tests on copper and brass suggest strongly that the acid and alkaline impurities present in the atmosphere can have little, if any, influence on atmospheric corrosion fatigue, and that oxygen in the presence of moisture is probably primarily responsible. The results of the tests on oxygen-containing and deoxidised coppers show that the comparative behaviour of these materials, when tested in air and in a partial vacuum, is unaffected by the different compositions of the dissolved gases present. Corrosion fatigue, in this instance of duralumin, is also the subject of the paper by Messrs. I. J. Gerard and H. Sutton, who show that coatings of organic resins and enamels afford a very high degree of protection, especially when the metal had previously been subjected to the anodic treatment. The best results were obtained with a coating of synthetic resin varnish stoved for two hours at $150^{\circ} \mathrm{C}$., metal so treated giving a fatigue limit of plus or minus $12 \cdot 2$ tons per square inch for ten million reversals.

Other papers were concerned with the reduction by hydrogen of stannic oxide in high conductivity copper, by Dr. Alkins and Mr. A. P. C. Hallowes, the spectrographic analysis of aluminium and a consideration of certain phases in the silver-cadmium alloys.

F. C. T.

\section{Science News a Century Ago}

\section{Shipping Statistics for 1834}

On April 20, 1835, Lieut.-Col. Sykes communicated to the Statistical Society an appendix to his paper on "The Increase of Wealth and Expenditure in the Various Classes of Society". In this he gave particulars of shipping and trade from January 5, 1834 until January 5, 1835. The increase in this period in the number of British vessels employed in foreign commerce, he said, was 689 ships of 108,562 tons burthen, value $£ 1,411,356$. The net receipts in the Customs duties had risen from $£ 17,577,549$ to $£ 19,931,687$. In the year there cleared inwards 11,678 British vessels employed in the foreign trade of a burthen of $2,108,492$ tons, which at $£ 12$ a ton represented a capital embarked of $£ 25,301,904$. The increase in the declared value of exports of the British and Irish manufacturers was $£ 2,052,542$, the total amount for the year being $£ 36,541,926$. The surplus disposable balance of the public revenue for the year ending January 5,1835 was $£ 1,608,155$ after payment of all charges.

\section{Meteorological Observations by Sir John Herschel}

The Athenceum of April 25, 1835, contained a long abstract from a letter from Sir John Herschel at the Cape, to J. Hudson, late assistant secretary to the Royal Society. The letter dealt mainly with meteorology, and in it Herschel said that the South African Literary and Philosophical Institution had appointed a Meteorological Committee and had passed a resolution that "On four fixed days in each year, 21 st of March, 21st of June, 21st of September and 21st of December . . . we undertake to make horary observations of the barometer, wet and dry thermometer, clouds, wind, meteors, ete. etc. at the commencement of each hour (per elock) mean time at the place for thirty-six hours, beginning at six o'clock in the morning of the 21st and ending at six o'clock in the evening of the 22 nd. Thus a complete twenty-four hours is sure to be embraced in corresponding, or at least, interpolable observations for all longitudes". Speaking of his measures with his actinometer, Herschel said, "The following may give you some notion of the purity of our sky and the force of our sunshine :

Effect observed here the day before yesterday $48^{\circ} 75$

Usual effect of ordinary good sunshine in England $25^{\circ} 30$

I find this instrument extremely sure and uniform in its indications, and having now had nearly eleven years' experience of it, I can safely say that it is perfectly adapted to the purpose. For this reason I shall draw up and forward to the Royal Society, very shortly an account of its construction and use".

\section{Death of Capt. Henry Kater}

On April 26, 1835, Capt. Henry Kater died in London. Born at Bristol on April 16, 1777, he came of a family of German extraction. At first he studied law, but at his father's death in 1794 he joined the Army as an ensign and sailed for India. There he came under Lambton's notice, and was employed on geodetical work. After a few years work in various parts of India, ill-health drove him home, and after further service in England in 1814 he was placed on half-pay and henceforth devoted himself to science.

Kater was best known for his geodetical work. His memoirs in the Philosophical Transactions from 1813 until 1828 refer mainly to the accurate construction and use of the pendulum, the balance and astronomical instruments. He applied Huygens's principle of the reciprocity of the centres of oscillation and suspension of pendulums; in 1818 ascertained accurately the length of the seconds pendulum in London, and during 1821-23 was associated with Arago, Mathieu and Colby in the determination of the difference of longitude between Paris and Greenwich. He compared the standard weights and measures of France, England and Russia, and also constructed various standards for Russia. Elected fellow of the Royal Society in 1815, he was awarded the Copley Medal in 1817 for his experiments on pendulums, and from November 1827 until November 1830 was treasurer to the Royal Society. 